\title{
Front Matter: Volume 12127
}

, "Front Matter: Volume 12127," Proc. SPIE 12127, International Conference on Intelligent Equipment and Special Robots (ICIESR 2021), 1212701 (12 December 2021); doi: 10.1117/12.2626014 (ICIESR 2021), 2021, Qingdao, China 


\section{PROCEEDINGS OF SPIE}

\section{International Conference on Intelligent Equipment and Special Robots (ICIESR 2021)}

Qiang Zhang

Zhong You

Editors

29-31 October 2021

Qingdao, China

Organized by

Shandong University of Science and Technology (China)

International Society for Intelligent Manufacturing (China)

Sponsored by

AEIC Academic Exchange Information Center

Published by

SPIE 
The papers in this volume were part of the technical conference cited on the cover and title page. Papers were selected and subject to review by the editors and conference program committee. Some conference presentations may not be available for publication. Additional papers and presentation recordings may be available online in the SPIE Digital Library at SPIEDigitalLibrary.org.

The papers reflect the work and thoughts of the authors and are published herein as submitted. The publisher is not responsible for the validity of the information or for any outcomes resulting from reliance thereon.

Please use the following format to cite material from these proceedings:

Author(s), "Title of Paper," in International Conference on Intelligent Equipment and Special Robots (ICIESR 2021), edited by Qiang Zhang, Zhong You, Proc. of SPIE 12127, Seven-digit Article CID Number (DD/MM/YYYY); (DOI URL).

ISSN: 0277-786X

ISSN: 1996-756X (electronic)

ISBN: 9781510651302

ISBN: 9781510651319 (electronic)

Published by

SPIE

P.O. Box 10, Bellingham, Washington 98227-0010 USA

Telephone +1 3606763290 (Pacific Time)

SPIE.org

Copyright @ 2021 Society of Photo-Optical Instrumentation Engineers (SPIE).

Copying of material in this book for internal or personal use, or for the internal or personal use of specific clients, beyond the fair use provisions granted by the U.S. Copyright Law is authorized by SPIE subject to payment of fees. To obtain permission to use and share articles in this volume, visit Copyright Clearance Center at copyright.com. Other copying for republication, resale, advertising or promotion, or any form of systematic or multiple reproduction of any material in this book is prohibited except with permission in writing from the publisher.

Printed in the United States of America by Curran Associates, Inc., under license from SPIE.

Publication of record for individual papers is online in the SPIE Digital Library.

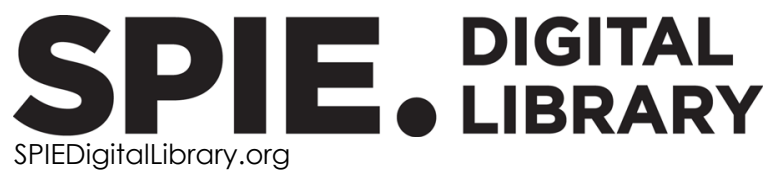

Paper Numbering: A unique citation identifier (CID) number is assigned to each article in the Proceedings of SPIE at the time of publication. Utilization of CIDs allows articles to be fully citable as soon as they are published online, and connects the same identifier to all online and print versions of the publication. SPIE uses a seven-digit CID article numbering system structured as follows:

- The first five digits correspond to the SPIE volume number.

- The last two digits indicate publication order within the volume using a Base 36 numbering system employing both numerals and letters. These two-number sets start with 00, 01, 02, 03, 04, $05,06,07,08,09,0 A, 0 B \ldots$. OZ, followed by 10-1Z, 20-2Z, etc. The CID Number appears on each page of the manuscript. 


\section{Contents}

\section{INTELLIGENT DEVICE DESIGN AND INTELLIGENT DETECTION TECHNOLOGY}

1212702 A non-contact picking device based on the coupling action of ultrasonic levitation and vacuum adsorption [12127-61]

1212703 Atomization analysis of coal caving dust reduction device in working face [12127-52]

1212704 Optimization design of air filter and integrated device for roots blower [12127-111]

1212705 Design of coding device based on color characteristics and K-means separable [12127-47]

1212706 Analysis of the influence of accumulator on the stability of liquid supply of emulsion pump station [12127-25]

1212707 Design and simulation analysis of terminal execution device of soft worm-like [12127-42]

1212708 Effect of operating parameters on flow field and classification performance of double vortex finder hydrocyclones [12127-38]

$1212709 \quad$ Fluid pipe network intelligent detection and warning [12127-53]

12127 OA Fault diagnosis of rolling bearing based on a mine fan bearing [12127-45]

$12127 \mathrm{OB} \quad$ Method of detecting wear of rigid tank way of vertical shaft based on machine vision [12127-50]

12127 OC Research on on-line high-precision detection technology of outer diameter for piston pins [12127-118]

12127 OD Dynamic characteristics analysis of triangular damping groove in port plate of double compound axial piston pump [12127-54]

12127 OE The mixing oil loss analysis of planetary gear train based on MPS method [12127-51]

$12127 \mathrm{OF}$ The chatter characteristics and suppression strategy of drilling hard and brittle materials based on axial-torsional coupling [12127-43]

$121270 G \quad$ Structure optimization design of traction fertilizer spreader [12127-64]

$12127 \mathrm{OH} \quad$ Fault diagnosis of rolling bearing based on CS-fuzzy neural network and wavelet packet transform [12127-137]

12127 Ol Design of fuzzy adaptive synovial control system for lower limb exoskeleton [12127-76] 
12127 0J Tear detection of conveyor belt based on machine vision [12127-32]

12127 OK A bearing fault diagnosis method based on improved convolution neural network and transfer learning [12127-127]

$12127 \mathrm{OL} \quad$ Study of air atomization gun operating parameters on flow field characteristics [12127-115]

$12127 \mathrm{OM}$ Analysis and design of a water-cooling structure for 18650 cylindrical battery [12127-123]

12127 ON Simulation and experimental study on buffer characteristics of a new mandrel type hydraulic buffer [12127-79]

1212700 Application of surface fitting to the problem of upward sliding of equipment on a coal workface [12127-55]

$12127 \mathrm{OP} \quad$ Stability of process parameters based on nonlinear forces in cylindrical micro-grinding [12127-65]

$12127 \mathrm{OQ}$ Application of intelligent monitoring and management technology for non-suspend air construction in airport engineering [12127-10]

12127 OR Test method for bridge wire temperature during ignition of electric explosive device [12127-130]

12127 OS Detection and analysis of gas pollutants in vehicle based on PID electronic nose [12127-4]

12127 OT Analysis of operation conditions of manned submersible in the North Indian Ocean [12127-2]

12127 OU Analysis of sea conditions for manned submersible operation in Northeast Pacific [12127-8]

12127 OV Optimization study on installation angle optimization of vacuum tube collector in high altitude towns in Western Sichuan [12127-11]

12127 OW Structural analysis and optimization of hydraulic lifting device for ground emergency rescue drilling rig [12127-6]

12127 OX Design and laboratory test of small diameter submersible pump [12127-9]

12127 OY Research on bomb simulation model [12127-5]

\section{SPECIAL ROBOTS AND ELECTROMECHANICAL CONTROL TECHNOLOGY}

$121270 Z$ Research on trajectory optimization of six-degree-of-freedom industrial robot [12127-27]

1212710 The underwater rolling capability of 3-RPS rolling robot [12127-91] 
$1212711 \quad$ Fuzzy sliding mode control of permanent magnet synchronous motor based on an improved index reaching law [12127-44]

1212712 Characteristic analysis of shearer drum cutting gangue coal and rock with different angles [12127-41]

1212713 Brief introduction of total-environment full-scale accelerated pavement loading facility [12127-33]

1212714 Research on adaptive trajectory following of lower limb rehabilitation exoskeleton based on sliding mode control [12127-84]

$1212715 \quad$ Modular design of small underwater robot control system [12127-85]

1212716 A bone recognition method of vertebral plate grinding of spine surgery robot [12127-78]

$1212717 \quad$ Research on adaptive cutting optimization of shearer in coal seam with gangue [12127-63]

1212718 Optimal design and resistance analysis of underwater biological monitoring robot [12127-97]

1212719 Structure optimization and gait analysis of parallel quadruped robot [12127-40]

$121271 \mathrm{~A} \quad$ Slip recognition and fuzzy control of belt conveyor inspection robot [12127-105]

12127 1B Learning to walk with biped robot based on an improved proximal policy optimization algorithm [12127-96]

12127 1C Research progress and theoretical analysis of robot formation control [12127-126]

12127 1D Research on the docking and positioning technology based on multi-sensor fusion for submarine cable inspection robot [12127-120]

12127 1E A trajectory planning method of vertebral plate grinding of spine surgery robot [12127-81]

12127 IF Forward kinematics of parallel robot based on neural network Newton-Raphson iterative algorithm [12127-36]

12127 1G Stabilization control of under-actuated mechanical system based on improved NPSO-PID controller [12127-68]

$12127 \mathrm{1H} \quad$ Research on autonomous exploration motion planning method of mobile robots for unstructured scenarios [12127-30]

$1212711 \quad$ Dynamic characteristics and reduction mechanism considering frictional self-excited chatter in micro-cutting [12127-60]

12127 1J Research on 4WS-DS control strategy of electric wheel vehicle [12127-124] 
$12127 \mathrm{~K} \quad$ Compensation control and simulation of a tendon-sheath transmission system applied to lower limb exoskeleton robots [12127-119]

$12127 \mathrm{lL} \quad$ Kinematic dexterity performance analysis of a parallel robot manipulator [12127-59]

$121271 \mathrm{M} \quad$ Finite element analysis of rock breaking experimental bench of high pressure water fracturing assisted pick [12127-74]

$121271 \mathrm{~N} \quad$ A novel bionic jellyfish robot for seabed rock drilling and sampling exploration [12127-136]

1212710 Shape optimization of underwater robots based on resistance reduction [12127-77]

12127 1P Kinematics analysis and simulation of a cooperative manipulator [12127-114]

$121271 Q \quad$ Structural design and motion analysis of adaptive pipeline robot [12127-131]

12127 IR Simplified analysis of dynamic machine foundation-subgrade dynamic interaction [12127-18]

12127 is Optimization design study of monolayer steel frame structures in power substation [12127-14]

12127 IT Resistivity response characteristics of X5 collapse column in Shiquan coal mine [12127-129]

$121271 \mathrm{U} \quad$ Study on the technology of microwave in-drum drying [12127-17]

12127 IV Research on key technology of large diameter pressure relief drilling [12127-20]

$12127 \mathrm{lW} \quad$ Fixed point acoustic monitoring of marine organisms in open water intake channel of nuclear power plant [12127-16]

12127 1X Fault analysis and treatment of stator cooling water pump in a power plant [12127-15]

12127 IY Design of dynamic monitoring system of hoisting derrick based on wireless communication [12127-56]

\section{INTELLIGENT ALGORITHM ANALYSIS AND IMAGE TARGET DETECTION}

1212712 Performance analysis of Dyna-Q algorithm in unstable environment [12127-24]

1212720 Dynamic parameter identification method derived from dynamic forgetting factor recursive least square method [12127-93]

$1212721 \quad$ An improved RRT dual tree path planning algorithm [12127-49]

$1212722 \quad$ An improved adaptive genetic algorithm for job shop scheduling problem [12127-92] 
$1212723 \quad$ Improved RRT path planning algorithm based on growth evaluation [12127-122]

$1212724 \quad$ Fast detection algorithm for surface defects of metal parts based on YOLOv4-mobilenet network [12127-116]

1212725 Research on coal gangue detection algorithm based on YOLOv4 [12127-90]

1212726 Research on the application of low-light enhancement methods in radiographic inspection pretreatment [12127-82]

$1212727 \quad$ Research on process route method based on directed graph topological sorting [12127-26]

$1212728 \quad$ Natural light reconstruction of three-dimensional image based on two-step volume holography [12127-29]

$1212729 \quad$ Analysis of pressure resistance performance of mine borehole pressure pillows based on finite element method [12127-133]

12127 2A Numerical simulation of LIU-InSAFT imaging detection [12127-72]

$121272 \mathrm{~B} \quad$ Analysis on influencing factors of on-line high-precision outer diameter measurement for piston pins [12127-1 12]

12127 2C Accuracy analysis of three degrees of parallel mechanism based on Monte Carlo Simulation [12127-62]

12127 2D Multi-pedestrian tracking based on hierarchical Siamese Neural Network [12127-117]

$121272 \mathrm{E} \quad$ Coal rock interface recognition method based on forward detection of ground penetrating radar [12127-134]

$121272 \mathrm{~F} \quad$ Numerical analysis of heat transfer enhancement of helical tube with twisted tapes under oneside heating [12127-104]

$121272 \mathrm{G} \quad$ Research on surface defect detection method of steel parts based on barkhausen effect [12127-66]

$121272 \mathrm{H} \quad$ Research on dimension reduction method of target object classification based on visual touch fusion [12127-87]

$1212721 \quad$ Research on the influence of contraction curve on the flow field performance of Laval nozzle [12127-37]

$121272 \mathrm{~J} \quad$ On-line measuring system of moving up-down-shift in fully mechanized mining face based on lidar [12127-75]

$121272 \mathrm{~K} \quad$ Nonstationary signal de-noising method of slow-speed large-size slewing bearing using robust local mean decomposition [12127-31]

$121272 \mathrm{~L} \quad$ Research on weld defect detection based on eddy current thermal imaging [12127-67] 
3D point cloud relocation in the mine scene [12127-110]

$121272 \mathrm{~N} \quad$ Modeling and simulation analysis of a certain planetary gear [12127-89]

1212720 Comparison of consensus in different multi-agent networks with diverse time-delays [12127-128]

$121272 P \quad$ Prediction of pick wear degradation based on Wiener process [12127-35]

$121272 Q \quad$ Seismic vulnerability analysis of aqueduct [12127-13]

$121272 R \quad$ A multi-path optimal communication (MPOC) technology of coal mine safety monitoring system [12127-3]

1212725 Study on prediction of spontaneous combustion fire in goaf of coal mine [12127-21]

$121272 T \quad$ Study on infrared detection of coal seam spontaneous combustion high temperature anomaly area [12127-23]

$121272 \mathrm{U}$ Statistical analysis of elevator failures and safety [12127-1]

$121272 \mathrm{~V} \quad$ Study on characteristics of shearer cutting coal with faults based on discrete element method [12127-135] 